UDC 343.775:502.3

LBC 67.408 .133

\title{
ISSUES ON THE ELIMINATION OF CRIME POLLUTION OF ATMOSPHERE FROM OFFENSES AND OTHER CRIMINAL COMPOSITIONS
}

\author{
Olga A. Yakovleva \\ Volgograd State University, Volgograd, Russian Federation
}

Daniil A. Chuykin

Centre for Hygiene and Epidemiology of the Volgograd Region, Volgograd, Russian Federation

\begin{abstract}
Introduction: the issue of delimiting criminal acts from administrative offenses and other crimes lies at the centre of law enforcement practice. The delimitation of criminal pollution of the atmosphere from wrongs and criminal acts, including environmental offences is no exception. The goal of the work is to analyze the issues of delimiting criminal acts from administrative offenses and other crimes in the sphere of ecology. Methods: the methodological framework of the research is a set of methods of scientific knowledge, among which the main are the methods of system analysis and synthesis. Results: the work presents a detailed analysis of the objective and subjective features of essential elements of the offence under Art. 251 of the Criminal Code of the Russian Federation; other crimes committed in the sphere of ecology and a number of administrative ecological offenses. On the basis of the analysis it is proved that criminal pollution of the atmosphere is delimited from administrative offenses on the basis of public danger. Conclusions: the delimitation of the criminal pollution of the atmosphere from administrative offenses is primarily done on the basis of the social danger which includes the qualitative and quantitative criteria (object of legal protection, extent and significance of the harm done, form of guilt); the delimitation of criminal pollution of the atmosphere from other crime components is done by the object of legal protection (generic and specific object; different understanding of the category "atmospheric air" as applied to the articles of the Criminal Code of the Russian Federation), the signs of the objective side (deeds and consequences), by the form of guilt.
\end{abstract}

Key words: air pollution, administrative offenses, environmental crimes, sabotage, ecocide.

УДК 343.775:502.3

ББК 67.408 .133

\section{ВОПРОСЫ ОТГРАНИЧЕНИЯ ПРЕСТУПНОГО ЗАГРЯЗНЕНИЯ АТМОСФЕРЫ ОТ ПРАВОНАРУШЕНИЙ И ИНЫХ СОСТАВОВ ПРЕСТУПЛЕНИЙ}

\author{
Ольга Алексеевна Яковлева
}

Волгоградский государственный университет, г. Волгоград, Российская Федерация

\section{Даниил Александрович Чуйкин}

Центр гигиены и эпидемиологии Волгоградской области, г. Волгоград, Российская Федерация

Введение: вопрос отграничения преступных деяний от административных правонарушений и иных составов преступлений занимает одно из центральных мест в правоприменительной практике. Не является исключением и разграничение преступного загрязнения атмосферы от правонарушений - преступных деяний, в том числе экологической направленности.

В работе поставлена цель - проанализировать вопросы отграничения преступных деяний от административных правонарушений и иных составов преступлений в сфере экологии. Методы: методологическую основу данного исследования составляет совокупность методов научного познания, среди которых основное место занимают методы системного анализа и синтеза. Результаты: в работе представлен детальный анализ объективных и субъективных признаков состава преступления, предусмотренного ст. 251 УК РФ; иных преступлений, совершаемых в сфере экологии, и ряда административных правонарушений экологи- 
ческой направленности. На основе данного анализа обосновано суждение о том, что отграничение преступного загрязнения атмосферы от административных правонарушений в своей основе проводится по признаку общественной опасности. Выводы: отграничение преступного загрязнения атмосферы от административных правонарушений в первую очередь проводится по признаку общественной опасности, который включает в себя качественный и количественный критерий (объект правовой охраны, степень и существенность причиненного вреда, форма вины); отграничение преступного загрязнения атмосферы от иных составов преступлений проводится по объекту уголовно-правовой охраны (родовому и видовому; различному пониманию категории «атмосферный воздух» применительно к статьям Уголовного кодекса РФ), признакам объективной стороны (деяниям и последствиям), по форме вины.

Ключевые слова: загрязнение атмосферы, административные правонарушения, экологические преступления, диверсия, экоцид.

\section{Введение}

Вопрос отграничения преступных деяний от административных правонарушений и иных составов преступлений занимает одно из центральных мест в правоприменительной практике. Не является исключением и разграничение преступного загрязнения атмосферы от правонарушений - преступных деяний, в том числе экологической направленности.

\section{Отграничение}

\section{преступного загрязнения атмосферы} от административных правонарушений по признаку общественной опасности

Отграничение преступного загрязнения атмосферы от административных правонарушений в своей основе проводится по признаку общественной опасности. Часть 1 ст. 251 УК РФ не содержит конкретного описания вредных последствий, наступивших в результате нарушения правил выброса в атмосферу загрязняющих веществ или нарушения эксплуатации установок, сооружений и иных объектов [4, с. 302]. В данном случае, с точки зрения уголовного закона, признак «общественная опасность» является оценочным и формулируется как «существенный вред», сущность которого определяется правоприменителем в каждом конкретном случае. Так, согласно Санитарным нормам «Шум на рабочих местах, помещениях жилых, общественных зданий и на территории жилой застройки» безопасный уровень звукового давления от работы различного рода установок и устройств не должен превышать определенных частот, в частности 125-4 000 Гц. Превышение безопасных уровней шума свидетельству- ет о грубом нарушении п. 6.3 вышеуказанных Санитарных норм и способствует изменению природных физических свойств атмосферного воздуха, создавая тем самым угрозу причинения вреда здоровью человека [6, с. 147].

Кроме того, объективная сторона ч. 1 ст. 251 УК РФ включает признаки двух альтернативных деяний: нарушение правил выброса в атмосферу загрязняющих веществ и нарушение эксплуатации установок, в то время как ст. 8.21 КоАП регламентирует эти признаки в основном в квалифицированных составах. В частности, объективная сторона ч. 1 ст. 8.21 КоАП выражена в выбросе вредных веществ в атмосферный воздух или вредном физическом воздействии на объект охраны; ч. 2 ст. 8.21 КоАП-в нарушении условий специального разрешения на указанные выше действия; ч. 3 ст. 8.21 КоАП - в нарушении правил эксплуатации, неиспользовании сооружений, оборудования или аппаратуры для очистки газов и контроля выбросов вредных веществ в атмосферный воздух либо использовании неисправных указанных сооружений, оборудования или аппаратуры [1, с. 126]. Следовательно, признаки объективной стороны ч. 1 ст. 251 УК РФ фактически полностью включают признаки основного и квалифицированных составов ст. 8.21 КоАП, усиливая общественную опасность деяния вредными последствиями в виде загрязнения или иного изменения природных свойств воздуха. Квалифицированные составы ст. 251 УК РФ содержат дополнительные объекты уголовно-правовой охраны: ч. 2 ст. 251 УК РФ здоровье человека; ч. 3 ст. 251 УК РФ - жизнь человека, что, безусловно, характеризует качественный критерий признака общественной опасности и усиливает меру ответственности за данные деяния. 
Субъективная сторона анализируемых преступных деяний и административных правонарушений совпадает лишь в основном составе ст. 251 УК РФ и в основном и квалифицированных составах ст. 8.21 КоАП. Квалифицированные составы рассматриваемого преступления предусматривают неосторожную форму вины, выраженную в неосторожном причинении вреда здоровью и смерти человеку. Умысел направлен на нарушение правил и эксплуатации установок, сооружений и иных объектов, неосторожная форма вины выражена по отношению к последствиям. В этом случае деяние идентично по степени опасности административному проступку и лишь вредные последствия позволяют отнести его к преступлению.

Многочисленные составы административных правонарушений, сконструированные законодателем как формальные, предусматривающие ответственность за самовольное подключение и использование электрической, тепловой энергии, нефти или газа; за нарушение санитарно-эпидемиологических требований; за правонарушения в строительстве, промышленности, энергетике, на транспорте; в области дорожного движения, таможенного дела, предпринимательской деятельности (ст. 6.3, 6.4, 7.19, 9.1-9.12, 10.1-10.3, 11.2, 11.5, $11.8,11.14,11.16,11.20,11.28,12.5,12.28,12.31$. 13.1-13.9, 14.1, 14.2, 14.4, 14.15, 16.1, 16.2, 16.3, 16.6, 20.4, 20.6, 20.8, 20.12 КоАП РФ), создают угрозу загрязнения атмосферного воздуха. И только если в результате указанных деяний наступают вредные последствия, обладающие признаком «существенности», ответственность за их совершение наступает по соответствующим статьям Уголовного кодекса Российской Федерации [3, с. 415].

Основой разграничения ст. 251 УК РФ с иными составами преступлений являются родовой и видовой объекты уголовно-правовой охраны. Кроме того, правила конкуренции норм устанавливают приоритетность специальных норм над общими. Так, ст. 246, 247 УК РФ предусматривают в качестве последствий причинение вреда здоровью человека, массовую гибель животных либо иные тяжкие последствия (ст. 246); угрозу причинения существенного вреда здоровью человека или окружающей среде, а также ее загрязнение, отравление, заражение (ч. 2 ст. 247). Атмосферный воздух является одним из элементов окружающей среды, загрязнение атмосферного воздуха следует рассматривать как загрязнение окружающей среды. Следовательно, нарушение правил, предусмотренных ст. 246, 247 УК РФ, может являться причиной загрязнения атмосферы и нарушения ее физических свойств. Разграничение данных составов со ст. 251 УК РФ проводится по предмету преступления и по объективной стороне.

Преступление в виде загрязнения атмосферы в ч. 3 ст. 251 УК РФ следует прежде всего отграничивать от ч. 2 ст. 109 УК РФ «Причинение смерти по неосторожности» по родовому объекту преступления. В первом случае это общественная безопасность, во втором это личность как совокупность общественных благ. Кроме того, правовая норма, предусмотренная ч. 2 ст. 109 УК РФ, является общей, а правовая норма, предусмотренная ч. 3 ст. 251 УК РФ, - специальной. Специальная норма содержит дополнительные признаки и охватывает более узкий круг преступных деяний, поэтому при конкуренции общей и специальной норм применяется специальная норма [2, с. 37-39].

Состав нарушения требований охраны труда (ст. 143 УК РФ) находится в одной родовой группе (Преступления против личности) с составом причинения смерти по неосторожности (ст. 109 УК РФ). При нарушении правил охраны труда может быть загрязнен только воздух производственных помещений, рабочих зон. Таким образом, разграничение рассматриваемых нами составов преступлений - ст. 251 УК РФ и ст. 143 УК РФ - происходит по объекту, предмету и специфике нарушенных правил.

Составы: нарушение правил безопасности на объектах атомной энергетики (ст. 215 УК РФ); нарушение правил безопасности при ведении горных, строительных или иных работ (ст. 216 УК РФ); нарушение правил безопасности на взрывоопасных объектах (ст. 217 УК РФ); нарушение требований пожарной безопасности (ст. 219 УК РФ) - объединены со ст. 251 УК РФ родовым объектом, но отграничены видовыми группами (гл. 24, 26 УК РФ), кроме того, для целей данных статей воздух рассматривается как смесь газов ат- 
мосферы в жилых, производственных и иных помещениях, а для целей ст. 251 УК РФ - находящихся за пределами последних.

Отграничение ст. 236 УК РФ «Нарушение санитарно-эпидемиологических правил〉 от ст. 251 УК РФ производится по основному видовому объекту (родовая группа идентична) посягательства. В первом случае в качестве объекта законодатель предусматривает здоровье населения, во втором случае в качестве основного объекта общественные отношения в области охраны атмосферы как одного из составляющих природно-ресурсного комплекса Российской Федерации, дополнительным же объектом в квалифицированных составах ст. 251 УК РФ является здоровье человека. Кроме того, в ст. 236 УК РФ рассматривается воздух, находящийся внутри помещения, тогда как в ст. 251 УК РФ речь идет об атмосферном воздухе - естественной смеси газов атмосферы, находящейся за пределами жилых, производственных и иных помещений [5, ст. 1].

Загрязнение атмосферы сходно с таким составом преступления, как диверсия (ст. 281 УК РФ), так как данный состав в качестве вредных последствий предусматривает разрушение объектов жизнеобеспечения. Отличие между данными деяниями производится по признаку объекта и вследствие установления мотивов и целей их совершения. Диверсия находится в родовой группе преступлений против государственной власти, загрязнение атмосферы - в родовой группе преступлений против общественной безопасности. Целью совершения диверсии является подрыв экономической безопасности и обороноспособности Российской Федерации.

По аналогичным признакам можно разграничивать анализируемое преступное деяние и экоцид (ст. 358 УК РФ). Экоцид относится к преступлениям против мира и безопасности человечества, и при его совершении субъект руководствуется целью вызвать экологическую катастрофу.

\section{Выводы}

Таким образом, учитывая вышеизложенный материал, касающийся вопроса отграничения преступного загрязнения атмосферы от правонарушений и иных составов преступлений, можно сделать следующие выводы: отграничение преступного загрязнения атмосферы от административных правонарушений в первую очередь проводится по признаку общественной опасности, который включает в себя качественный и количественный критерии (объект правовой охраны, степень и существенность причиненного вреда, форма вины); отграничение преступного загрязнения атмосферы от иных составов преступлений проводится по объекту уголовно-правовой охраны (родовому и видовому; различному пониманию категории «атмосферный воздух» применительно к статьям Уголовного кодекса РФ), признакам объективной стороны (деяниям и последствиям), по форме вины.

\section{СПИСОК ЛИТЕРАТУРЫ}

1. Кодекс Российской Федерации об административных правонарушениях : [текст с изм. и доп. на 1 сент. 2016 г.]. - М. : Эксмо, 2016. - 464 с.

2. Рарог, А. И. Настольная книга судьи по квалификации преступлений / А. И. Рарог. - М. : Велби : Проспект, 2008. - 224 с.

3. Российское уголовное право. В 2 т. Т. 2. Особенная часть / Г. Н. Борзенков [и др.]. - М. : Велби : Проспект, 2006. $-656 \mathrm{c}$.

4. Уголовный кодекс Российской Федерации : [по состоянию на 1 окт. 2016 г., с коммент. к послед. изм.]. - М. : Эксмо, 2016. - 448 с.

5. Федеральный закон «Об охране атмосферного воздуха» от 4 мая 1999 г. № 96-Ф3 : (ред. от 13 июля 2015 г.). - Доступ из справ.-правовой системы «КонсультантПлюс».

6. Яковлева, О. А. Криминалистическая характеристика и первоначальный этап расследования экологических преступлений, связанных с нарушением правил охраны окружающей среды при производстве работ / О. А. Яковлева. - Волгоград : Изд-во ВолГУ, 2006. -200 с.

\section{REFERENCES}

1. Kodeks Rossiyskoy Federatsii ob administrativnykh pravonarusheniyakh : tekst s izm. $i$ dop. na 1 sent. $2016 \mathrm{~g}$. [The Code of the Russian Federation on Administrative Offenses: Text with Amendments and Additions as of September 1, 2016]. Moscow, Eksmo Publ., 2016. 464 p.

2. Rarog A.I. Nastolnaya kniga sudyi po kvalifikatsii prestupleniy [The Judge's Desk Book on 
the Qualification of Crimes]. Moscow, Velbi Publ.; Prospekt Publ., 2008. 224 p.

3. Borzenkov G.N., et al. Rossiyskoe ugolovnoe pravo. V2 t. T. 2. Osobennaya chast [Russian Criminal Law. In 2 vols. Vol. 2 Special Part]. Moscow, Velbi Publ.; Prospekt Publ., 2006. 656 p.

4. Ugolovnyy kodeks Rossiyskoy Federatsii: po sostoyaniyu na 1 okt. 2016 g., s komment. kposled. izm. [The Criminal Code of the Russian Federation: as of October 1, 2016, with comments on the latest amendments]. Moscow, Eksmo Publ., 2016. 448 p.

5. Federalnyy zakon «Ob okhrane atmosfernogo vozdukha» ot 4 maya 1999 g. № 96-FZ: (red. ot
13 iyulya 2015 g.) [The Federal Law “On Protection of Atmospheric Air" of May4, 1999 no. 96-FL: (as amended on July 13, 2015)]. Access from KonsultantPlyus reference legal system.

6. Yakovleva O.A. Kriminalisticheskaya kharakteristika i pervonachalnyy etap rassledovaniya ekologicheskikh prestupleniy, svyazannykh s narusheniem pravil okhrany okruzhayushchey sredy pri proizvodstve rabot [Criminalistic Characteristics and the Initial Stage of the Investigation of Environmental Crimes Related to Violation of the Environmental Protection Rules in the Production of Works]. Volgograd, Izd-vo VolGU, 2006. 200 p.

\section{Information about the Authors}

Olga A. Yakovleva, Candidate of Juridical Sciences, Associate Professor, Department of Criminal Law, Volgograd State University, Prosp. Universitetsky, 100, 400062 Volgograd, Russian Federation, olgayakovlev@mail.ru,up@volsu.ru.

Daniil A. Chuykin, Legal Advisor, Centre for Higiene and Epidemiology of the Volgograd Region, Angarskaya St., 13b, 400049 Volgograd, Russian Federation, chdafw@mail.ru.

\section{Информация об авторах}

Ольга Алексеевна Яковлева, кандидат юридических наук, доцент кафедры уголовного права, Волгоградский государственный университет, просп. Университетский, 100, 400062 г. Волгоград, Российская Федерация, olgayakovlev@mail.ru, up@volsu.ru.

Даниил Александрович Чуйкин, юрисконсульт, Центр гигиены и эпидемиологии Волгоградской области, ул. Ангарская, 13б, 400049 г. Волгоград, Российская Федерация, chdafw@mail.ru. 